\title{
Rapid report
}

\section{Isotopic discrimination of zinc in higher plants}

Author for correspondence: D. J. Weiss

Tel: +44 (0)2075946383

Fax: +44 (0)207594 7444

Email:d.weiss@imperial.ac.uk

Received: 27 October 2004

Accepted: 23 November 2004

\author{
D. J. Weiss ${ }^{1,2, *}$, T. F. D. Mason ${ }^{1}$, F. J. Zhao ${ }^{3}$, G. J. D. Kirk ${ }^{4}$, B. J. Coles ${ }^{1}$ \\ and M. S. A. Horstwood ${ }^{5}$ \\ ${ }^{1}$ Department of Earth Science and Engineering, Imperial College London, London, SW7 2AZ, UK; \\ ${ }^{2}$ Department of Mineralogy, Natural History Museum, London, SW7 5BD, UK; ${ }^{3}$ Agriculture and \\ Environment Division, Rothamsted Research, Harpenden, AL5 2JQ, UK; ${ }^{4}$ National Soil Resources \\ Institute, Cranfield University, Silsoe, MK45 4DT, UK; ${ }^{5}$ NERC Isotope Geosciences Laboratory, \\ Keyworth, NG12 5GG, UK
}

\section{Summary}

Key words: fractionation, isotopic discrimination, plant uptake, stable isotopes, zinc (Zn).
- The extent of isotopic discrimination of transition metals in biological processes is poorly understood but potentially has important applications in plant and biogeochemical studies.

- Using multicollector inductively coupled plasma (ICP) mass spectrometry, we measured isotopic fractionation of zinc ( $\mathrm{Zn}$ ) during uptake from nutrient solutions by rice (Oryza sativa), lettuce (Lactuca sativa) and tomato (Lycopersicon esculentum) plants.

- For all three species, the roots showed a similar extent of heavy Zn enrichment relative to the nutrient solution, probably reflecting preferential adsorption on external root surfaces. By contrast, a plant-species specific enrichment of the light $\mathrm{Zn}$ isotope occurred in the shoots, indicative of a biological, membrane-transport controlled uptake into plant cells. The extent of the fractionation in the shoots further depended on the $\mathrm{Zn}$ speciation in the nutrient solution.

- The observed isotopic depletion in heavy $\mathrm{Zn}$ from root to shoot (-0.13 to - $0.26 \%$ 。 per atomic mass unit) is equivalent to roughly a quarter of the total reported terrestrial variability of $\mathrm{Zn}$ isotopic compositions (c. $0.84 \%$ oper atomic mass unit). Plant uptake therefore represents an important source of isotopic variation in biogeochemical cycling of $\mathrm{Zn}$.

New Phytologist (2005) 165: 703-710

(C) New Phytologist (2004) doi: 10.1111/j.1469-8137.2004.01307.x

\section{Introduction}

Stable isotope ratios are routinely used in studying the biogeochemical cycling of light elements such as carbon (C), oxygen $(\mathrm{O})$, nitrogen $(\mathrm{N})$ and sulphur $(\mathrm{S})$ in the environment (Hoefs, 1987). Examples include studies of the mechanisms of photosynthesis and of nutrient uptake and translocation in plants (Taiz \& Zeiger, 2002). However, equivalent methods have not been available for heavier elements with atomic masses above $c .40$ atomic mass units ( $\mathrm{amu}$ ), such as zinc $(\mathrm{Zn})$, due to instrumental limitations. But since the development of the multicollector inductively coupled plasma mass spectrometer (MC-ICP-MS), in which a high-temperature plasma achieves high ionization and a multiple array of collectors allows simultaneous mass determinations, extremely precise isotope ratio measurements of heavier elements have become possible 
(Halliday et al., 1998). This has led to the discovery of significant isotope fractionation of transition elements in nature resulting from equilibrium and kinetic reactions in both biotic and abiotic processes, notably for iron (Fe) (Anbar et al., 2000; Zhu et al., 2002; Beard et al., 2003) and for $\mathrm{Zn}$ and copper (Cu) (Maréchal et al., 1999, 2000; Maréchal \& Albarède, 2002; Zhu et al., 2002). However, to date there have been no systematic studies with plants.

The objectives of this study were to assess if isotopic fractionation of $\mathrm{Zn}$ occurs during its uptake by higher plants and to explore possible mechanisms. We conducted experiments in hydroponic cultures with three plant species (one monocotyledon and two dicotyledons) and two nutrient solutions differing in $\mathrm{Zn}$ speciation.

\section{Materials and Methods}

\section{Plant growth}

Seeds of rice (Oryza sativa L.) cv. IR64 were obtained from the International Rice Research Institute (Manila, Philippines), and seeds of lettuce (Lactuca sativa L.) cv. 'Romana' and tomato (Lycopersicon esculentum L.) cv. 'Alicante' were obtained from Johnson Seeds (Newmarket, Suffolk, UK). All seeds were washed in running deionised water before being germinated in the dark on moistened filter paper for $5-10 \mathrm{~d}$. The seedlings were then transferred to blackened polycarbonate pots containing 11 of nutrient solution with five plants per pot.
Two nutrient solutions were used: (1) an ethylenediaminetetraacetic acid (EDTA) buffered solution prepared with equimolar proportions of EDTA and Fe; and (2) an $N-(2-$ hydroxyethyl)ethylenediaminetriacetic acid (HEDTA) + nitrolotriacetic acid (NTA) buffered solution which contained $70 \mu \mathrm{mol}$ excess chelator over the sum of $\mathrm{Fe}, \mathrm{Zn}, \mathrm{Cu}$ and manganese (Mn). Nutrient stock solutions were prepared gravimetrically from analytical grade reagents, from which final nutrient solutions were prepared in deionised water. The $\mathrm{pH}$ of the nutrient solution was buffered at 6.0 with $2(\mathrm{~N}-$ morpholino)-ethanesulfonic acid (MES; $2 \mathrm{~mm}$ in the nutrient solutions), adjusted using analytical grade $1 \mathrm{~m} \mathrm{KOH.} \mathrm{Zinc}$ contaminants in the deionised water were insignificant compared with the contribution from the stock solutions. Table 1 shows the total concentrations, free ion activities and speciation data for both nutrient solutions.

Eight replicates for rice and four replicates each for lettuce and tomato were prepared for each nutrient solution. Plants were grown for $42 \mathrm{~d}$ under controlled conditions (16 h photoperiod with a white light intensity of $350 \mu$ mol photons $\mathrm{m}^{-2} \mathrm{~s}^{-1}$; day : night temperatures $25: 18^{\circ} \mathrm{C}$; relative humidity $60-70 \%)$. For the first $21 \mathrm{~d}$, nutrient solutions were changed weekly, after which they were changed every 3-4 d to avoid nutrient depletion. Water lost through transpiration was replaced daily. Nutrient solutions were aerated throughout the experiment. The nutrient solutions were left after the preparation for $1 \mathrm{~d}$ before use to ensure that the Zn-EDTA, $\mathrm{Zn}$-HEDTA and Zn-NTA complexes in the nutrient solutions

Table 1 Total concentrations, free ion activities and speciation data for the HEDTA + NTA and EDTA nutrient solutions used in the hydroponic study. All data were calculated using GEOCHEM-PC (Parker et al., 1995) and a fixed solution pH of 6.0. Charge balance calculations for the HEDTA + NTA and EDTA nutrient solutions give values of $2.8 \%$ and $3.8 \%$, respectively, indicating that the model fits the concentration data reasonably well. lonic strengths for the HDTA + NTA and EDTA solutions equal 0.0158 and $0.0155 \mathrm{M}$, respectively

\begin{tabular}{|c|c|c|c|c|c|c|c|c|c|c|}
\hline \multirow[b]{2}{*}{ Metal } & \multicolumn{2}{|c|}{ HEDTA + NTA nutrient solution } & \multicolumn{8}{|c|}{ Proportion associated with indicated ligand in solution (\%) } \\
\hline & Conc. (M) & Free ion activity & Free metal & $\mathrm{SO}_{4}^{2-}$ & $\mathrm{Cl}^{-}$ & $\mathrm{PO}_{4}{ }^{3-}$ & $\mathrm{NO}_{3}^{-}$ & HEDTA & NTA & MES \\
\hline $\mathrm{Ca}^{2+}$ & $1.00 \mathrm{E}-03$ & $4.91 \mathrm{E}-04$ & 81.18 & 14.98 & 0.01 & 0.25 & $<0.01$ & 0.08 & 2.54 & 0.95 \\
\hline $\mathrm{Mg}^{2+}$ & $1.64 \mathrm{E}-03$ & $8.48 \mathrm{E}-04$ & 85.51 & 12.54 & 0.12 & 0.22 & $<0.01$ & $<0.01$ & 0.34 & 1.26 \\
\hline $\mathrm{K}^{+}$ & $4.99 \mathrm{E}-03$ & $4.34 \mathrm{E}-03$ & 98.76 & 1.20 & 0.04 & $<0.01$ & $<0.01$ & $<0.01$ & $<0.01$ & $<0.01$ \\
\hline $\mathrm{Na}^{+}$ & $4.00 \mathrm{E}-07$ & $3.49 \mathrm{E}-07$ & 99.03 & 0.76 & 0.20 & $<0.01$ & $<0.01$ & $<0.01$ & $<0.01$ & $<0.01$ \\
\hline $\mathrm{Fe}^{3+}$ & $2.00 \mathrm{E}-04$ & $8.72 \mathrm{E}-16$ & $<0.01$ & $<0.01$ & $<0.01$ & $<0.01$ & $<0.01$ & 85.17 & 14.83 & $<0.01$ \\
\hline $\mathrm{Mn}^{2+}$ & $2.00 \mathrm{E}-05$ & $3.94 \mathrm{E}-06$ & 32.63 & 6.02 & 0.20 & $<0.01$ & $<0.01$ & 47.91 & 12.85 & 0.38 \\
\hline \multirow[t]{2}{*}{$\mathrm{Zn}^{2+}$} & $2.00 \mathrm{E}-06$ & $4.10 \mathrm{E}-10$ & 0.03 & $<0.01$ & $<0.01$ & $<0.01$ & $<0.01$ & 78.82 & 21.14 & $<0.01$ \\
\hline & \multicolumn{2}{|c|}{ EDTA nutrient solution } & \multicolumn{8}{|c|}{ Proportion associated with indicated ligand in solution (\%) } \\
\hline Metal & Conc. (M) & Free ion activity & Free metal & $\mathrm{SO}_{4}{ }^{2-}$ & $\mathrm{Cl}^{-}$ & $\mathrm{PO}_{4}{ }^{3-}$ & $\mathrm{NO}_{3}^{-}$ & EDTA & $\mathrm{OH}^{-}$ & MES \\
\hline $\mathrm{Ca}^{2+}$ & $1.00 \mathrm{E}-03$ & $5.06 \mathrm{E}-04$ & 83.48 & 15.37 & 0.01 & 0.15 & $<0.01$ & $<0.01$ & $<0.01$ & 0.98 \\
\hline $\mathrm{Mg}^{2+}$ & $1.64 \mathrm{E}-03$ & $8.55 \mathrm{E}-04$ & 85.92 & 12.57 & 0.11 & 0.13 & $<0.01$ & $<0.01$ & $<0.01$ & 1.27 \\
\hline $\mathrm{K}^{+}$ & $4.99 \mathrm{E}-03$ & $4.34 \mathrm{E}-03$ & 98.76 & 1.20 & 0.04 & $<0.01$ & $<0.01$ & $<0.01$ & $<0.01$ & $<0.01$ \\
\hline $\mathrm{Na}^{+}$ & $4.00 \mathrm{E}-07$ & $3.50 \mathrm{E}-07$ & 99.06 & 0.76 & 0.18 & $<0.01$ & $<0.01$ & $<0.01$ & $<0.01$ & $<0.01$ \\
\hline $\mathrm{Fe}^{3+}$ & $1.00 \mathrm{E}-04$ & $3.19 E-15$ & $<0.01$ & $<0.01$ & $<0.01$ & 40.95 & $<0.01$ & 19.21 & 39.83 & $<0.01$ \\
\hline $\mathrm{Mn}^{2+}$ & $2.00 \mathrm{E}-05$ & $1.01-05$ & 82.95 & 15.27 & 0.46 & $<0.01$ & $<0.01$ & 0.34 & $<0.01$ & 0.97 \\
\hline $\mathrm{Zn}^{2+}$ & $1.00 \mathrm{E}-06$ & $2.14 \mathrm{E}-07$ & 35.25 & 6.49 & 0.12 & 0.19 & 0.08 & 57.39 & 0.48 & $<0.01$ \\
\hline
\end{tabular}


were in equilibrium (Price et al., 1998). The total amount of $\mathrm{Zn}$ in the nutrient solution was always far in excess of the amount of $\mathrm{Zn}$ taken up by plants to avoid reservoir depletion effects.

Upon harvest, root and shoot fractions were separated, and all plant materials were washed in running deionised water to remove superficial nutrient solution. Root materials were submerged sequentially in two 1-1 baths of ice-cold deionised water for $5 \mathrm{~min}$ each to remove surface-bound nutrient solution. In addition, roots of four of the eight replicate rice samples were submerged in a $1-1$ bath of $1 \mathrm{~mm} \mathrm{LaCl}_{3}+0.05 \mathrm{~mm}$ $\mathrm{CaCl}_{2}$ for $10 \mathrm{~min}$ to remove apoplastically bound $\mathrm{Zn}$ (following Rengel, 1999).

\section{Sample preparation}

Oven-dried root and shoot specimens were ground using a porcelain pestle and mortar with liquid nitrogen to pass through a $0.5 \mathrm{~mm}^{2}$ sieve. Approximately $0.3 \mathrm{~g}$ of material were then digested in $6: 2: 1 \mathrm{ml}$ concentrated Aristar grade $\mathrm{HNO}_{3}$ : $\mathrm{H}_{2} \mathrm{O}_{2}: \mathrm{H}_{2} \mathrm{O}$ (Merk, Darmstadt, Germany) using a closed-vessel MarsX microwave digestion system (CEM Corporation, North Carolina, USA) (Dolgopolova et al., 2004). For the rice samples, $0.5 \mathrm{ml} \mathrm{HF}$ was included to break down biogenic silica.

Matrix components were separated from $\mathrm{Zn}$ prior to isotope analysis using an adapted anion exchange procedure previously described (Maréchal et al., 1999) and yielded quantitative recoveries of $\mathrm{Zn}$ from the plant matrix (Mason, 2003). Recovered $\mathrm{Zn}$ fractions were evaporated to dryness and residual $\mathrm{Cl}^{-}$and $\mathrm{Br}^{-}$ions were driven off by re-evaporating in $10 \mu \mathrm{l}$ ultra-pure conc. $\mathrm{HNO}_{3}$. Samples were subsequently dissolved in $0.05 \%\left(\mathrm{v} \mathrm{v}^{-1}\right)$ ultra-pure $\mathrm{HNO}_{3}$ and spiked with NIST-SRM $976 \mathrm{Cu}$. Sample and standard solutions were concentration-matched for $\mathrm{Zn}$ and $\mathrm{Cu}$ to within $\pm 0.05 \mu \mathrm{g}$ $\mathrm{ml}^{-1}$ prior to isotope analysis.

Procedural blanks for Zn were approx. $100 \mathrm{ng}$, reflecting absorption of $\mathrm{Zn}$ from the Aristar reagents used on to the ionexchange column during matrix separation. Isotopic analyses of procedural blanks indicate their compositions to be identical within error to that of the Johnson Matthey Purontronic ${ }^{\mathrm{TM}}$ (Alfa Aesar, Karlsruhe, Germany) Zn standard used. The procedural blank contribution accounted for $<3 \%$ of the $\mathrm{Zn}$ analysed in all cases, and calculations showed that at this level the procedural zinc blank has had a negligible influence on the isotope measurements within the achieved analytical reproducibility.

\section{Isotope analysis}

All $\mathrm{Zn}$ isotope compositions were measured using the ThermoElemental Axiom MC-ICP-MS at the NERC Isotope Geosciences Laboratories, Keyworth, UK. Mass spectrometric and data processing procedures followed previously described methods (Mason et al., 2004a,b). Samples were introduced

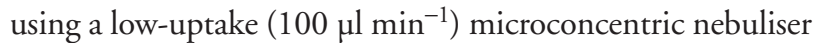
in combination with a water-cooled $\left(10^{\circ} \mathrm{C}\right)$ cyclonic and impact-bead spray chamber set-up. Peak intensities of ${ }^{63} \mathrm{Cu}^{+}$, ${ }^{64} \mathrm{Zn}^{+},{ }^{65} \mathrm{Cu}^{+},{ }^{66} \mathrm{Zn}^{+},{ }^{67} \mathrm{Zn}^{+}$and ${ }^{68} \mathrm{Zn}^{+}$were measured on Faraday detectors using a static collection protocol at a spectral resolution of $\mathrm{M} / \Delta \mathrm{M}=400$. Instrumental backgrounds and amplifier offsets were corrected using an on-peak acid blank subtraction procedure. Isobaric ${ }^{64} \mathrm{Ni}^{+}$and $\mathrm{Ba}^{2+}$-related interferences were corrected by monitoring secondary interference peaks at masses 62 and 67.5, respectively, using an off-line peak subtraction. Instrumental mass bias drift and sample-related non-spectral mass discrimination effects were accounted for using the approach of empirical external normalisation as previously described (Mason et al., 2004b). Samples were randomised to avoid systematic errors. Measurement solutions were prepared in $0.05 \%\left(\mathrm{v} \mathrm{v}^{-1}\right)$ ultra-pure $\mathrm{HNO}_{3}$ and matched to ensure approx. $4 \mathrm{~V}$ signals on ${ }^{63} \mathrm{Cu}$ and ${ }^{6} \mathrm{Zn}$ (typically at concentrations around $0.4 \mathrm{mg} \mathrm{ml}^{-1}$ for $\mathrm{Cu}$ and $1 \mathrm{mg} \mathrm{ml}^{-1}$ for $\mathrm{Zn}$ ). Analyses comprised 200 5-s integrations. No statistical outliers were rejected during data reduction.

All $\mathrm{Zn}$ isotope data are expressed relative to our in-house standard ( Johnson-Matthey Purontronic ${ }^{\mathrm{TM}}$ Batch NH 27040) using the conventional notation: $\delta^{66} \mathrm{Zn}(\%)=\left[\left\{\left({ }^{66} \mathrm{Zn} /{ }^{64} \mathrm{Zn}\right){ }_{\text {sample }} /\right.\right.$ $\left.\left.\left({ }^{66} \mathrm{Zn} /{ }^{64} \mathrm{Zn}\right)_{\text {standard }}\right\}-1\right] \times 1000$. Repeat measurements indicate that this standard is $0.044 \pm 0.035 \%$ o per atomic mass unit (pamu) ( $\pm 2 \mathrm{sD}$ ) isotopically heavier than the JohnsonMatthey Zn standard 3-0749 L (Maréchal et al., 1999). Total analytical errors associated with the isotope measurements, estimated from the standard deviation of repeated standard analyses over 9 months, gave a combined uncertainty in $\delta^{66} \mathrm{Zn}$ measurements of $\pm 0.07 \%$ ( $\left.\pm 2 \mathrm{sD}\right)$. This is in agreement with six repeated analyses of standard seeds of rice IR34 from the International Rice Research Institute during the same period, which give an average $\delta^{66} \mathrm{Zn}$ value of $0.631 \pm 0.046 \%$ o ( $\pm 2 \mathrm{SD})$.

\section{Results}

The isotopic variability of $\mathrm{Zn}$ in the three plant species is shown in Fig. 1. All three species showed a similar pattern of isotope discrimination in both nutrient solutions, with a small enrichment in heavy $\mathrm{Zn}\left({ }^{66} \mathrm{Zn}\right)$ between the bulk nutrient solution and root of $0.04-0.09 \%$ pamu, followed by an isotopic depletion in heavy $\mathrm{Zn}$ from root to shoot of -0.13 to $-0.26 \%$ pamu. These shifts are significant relative to the analytical reproducibility $( \pm 0.035 \%$ pamu $( \pm 2 \mathrm{sD}))$ and provide the first direct evidence of $\mathrm{Zn}$ isotope discrimination in higher plants. In general, more than $85 \%$ of the total plant $\mathrm{Zn}$ (unless in rice) was distributed in the shoots (Fig. 2) so that overall relatively light $\mathrm{Zn}$ was withdrawn from the nutrient solutions. The magnitudes of the shifts were similar between the nutrient solutions for solution-to-root transfer, but for root-to-shoot transfer the shift was significantly greater in 


\section{EDTA Solution}

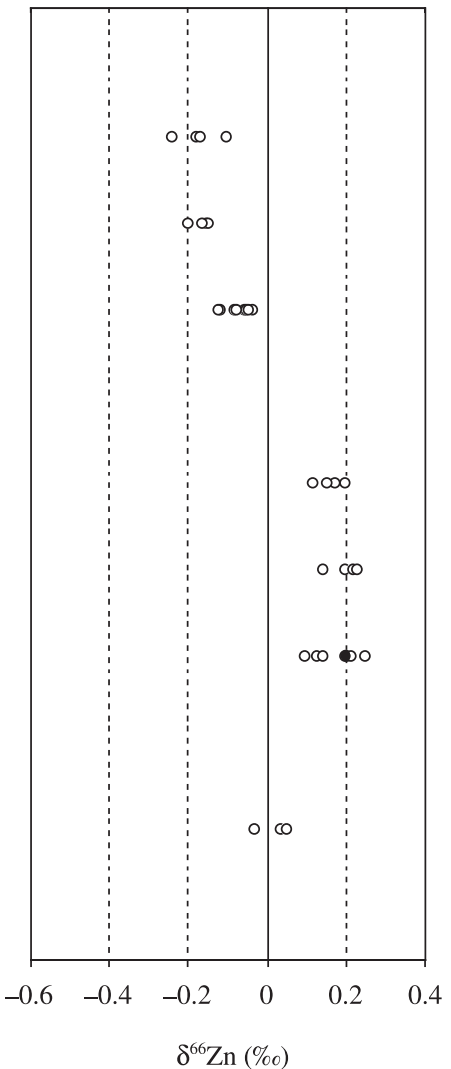

HEDTA+NTA Solution

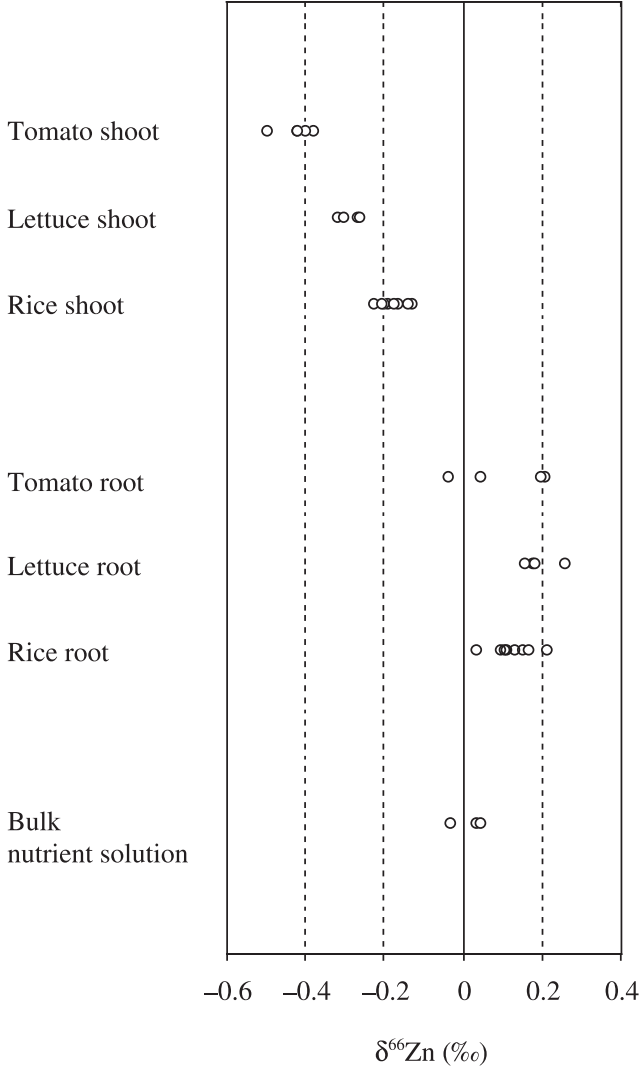

Fig. 1 Isotopic discrimination of zinc (Zn) in shoots and roots of rice (Oryza sativa), lettuce (Lactuca sativa) and tomato (Lycopersicon esculentum) grown in nutrient solutions containing either EDTA (left-hand panel) or excess HEDTA + NTA (right-hand panel) resulting in different concentrations of free $\mathrm{Zn}^{2+}$. The error of determination is estimated to be $\pm 0.07 \%$ o ( $\pm 2 \mathrm{SD}$ ). The average isotopic composition of naturally occurring $\mathrm{Zn}$ is ${ }^{64} \mathrm{Zn}$, $48.98 \% ;{ }^{66} \mathrm{Zn}, 27.81 \% ;{ }^{67} \mathrm{Zn}, 4.11 \% ;{ }^{68} \mathrm{Zn}$, $18.57 \% ;{ }^{70} \mathrm{Zn}, 0.62 \%$.
HEDTA + NTA than EDTA ( -0.15 to $-0.26 \%$ pamu compared with -0.13 to $-0.18 \%$ o pamu). The isotopic depletion within the shoots varied between the plant species, with tomato showing the greatest and rice the least depletion in heavy $\mathrm{Zn}$ (Fig. 1).

\section{Discussion}

The following five processes may contribute to the observed isotopic fractionation: (1) mobilisation of seed $\mathrm{Zn}$ reserves in the plants; (2) Zn speciation in the nutrient solution; (3) $\mathrm{Zn}$ uptake into roots; (4) Zn binding to root cell walls; and (5) $\mathrm{Zn}$ translocation from roots to shoots. We now discuss each of these in turn.

\section{Mobilisation of seed Zn}

Seed $\mathrm{Zn}$ reserves in the rice and lettuce were isotopically heavier than $\mathrm{Zn}$ in the bulk nutrient solution by 0.03 and $0.36 \%$ pamu, respectively. This heavy $\mathrm{Zn}$ could influence the isotopic composition of the roots and shoots if the seed reserves represented a significant proportion of the overall plant $\mathrm{Zn}$ budget. From the $\mathrm{Zn}$ contents of the seeds and whole plant (Fig. 2), however, we calculate that $>96.5 \%$ of the plant $\mathrm{Zn}$ budget originated from the nutrient solutions in all the plant species.
Therefore seed reserves would not have significantly affected the $\mathrm{Zn}$ isotopic compositions of the roots and shoots.

\section{Speciation in the nutrient solution}

Because free $\mathrm{Zn}^{2+}$ is preferentially taken up over complexed Zn species in higher plants (Hacisalihoglu \& Kochian, 2003), isotopic discrimination in the nutrient solutions during speciation will affect the isotopic composition of the plants. In the EDTA solution, $57 \%$ and $35 \%$ of the $\mathrm{Zn}$ is present as $\mathrm{Zn}$ EDTA and free $\mathrm{Zn}^{2+}$, respectively, and in the 'excess' HEDTA + NTA solution, > $99.9 \%$ of the $\mathrm{Zn}$ is chelated; only $0.03 \%$ is present as free $\mathrm{Zn}^{2+}$ (Table 1). Because of slight mass dependence of chemical bond strengths, isotopes of the same element are unequally distributed between different chemical species during equilibrium reactions, with heavy isotopes being preferentially partitioned into the complex with the strongest covalent character (Bigeleisen \& Mayer, 1947). As EDTA, HEDTA and NTA form strong covalent bonds with $\mathrm{Zn}^{2+}$, the chelated $\mathrm{Zn}$ fraction will approximate to the isotopic composition of the bulk nutrient solution, but the free $\mathrm{Zn}^{2+}$ fraction will be strongly enriched in isotopically light $\mathrm{Zn}\left({ }^{64} \mathrm{Zn}\right)$. The roots will also participate in this equilibrium as a result of $\mathrm{Zn}$ binding to root cell walls and uptake into the roots. However, because there is more than an order of magnitude more 
New

Phytologist

(a)
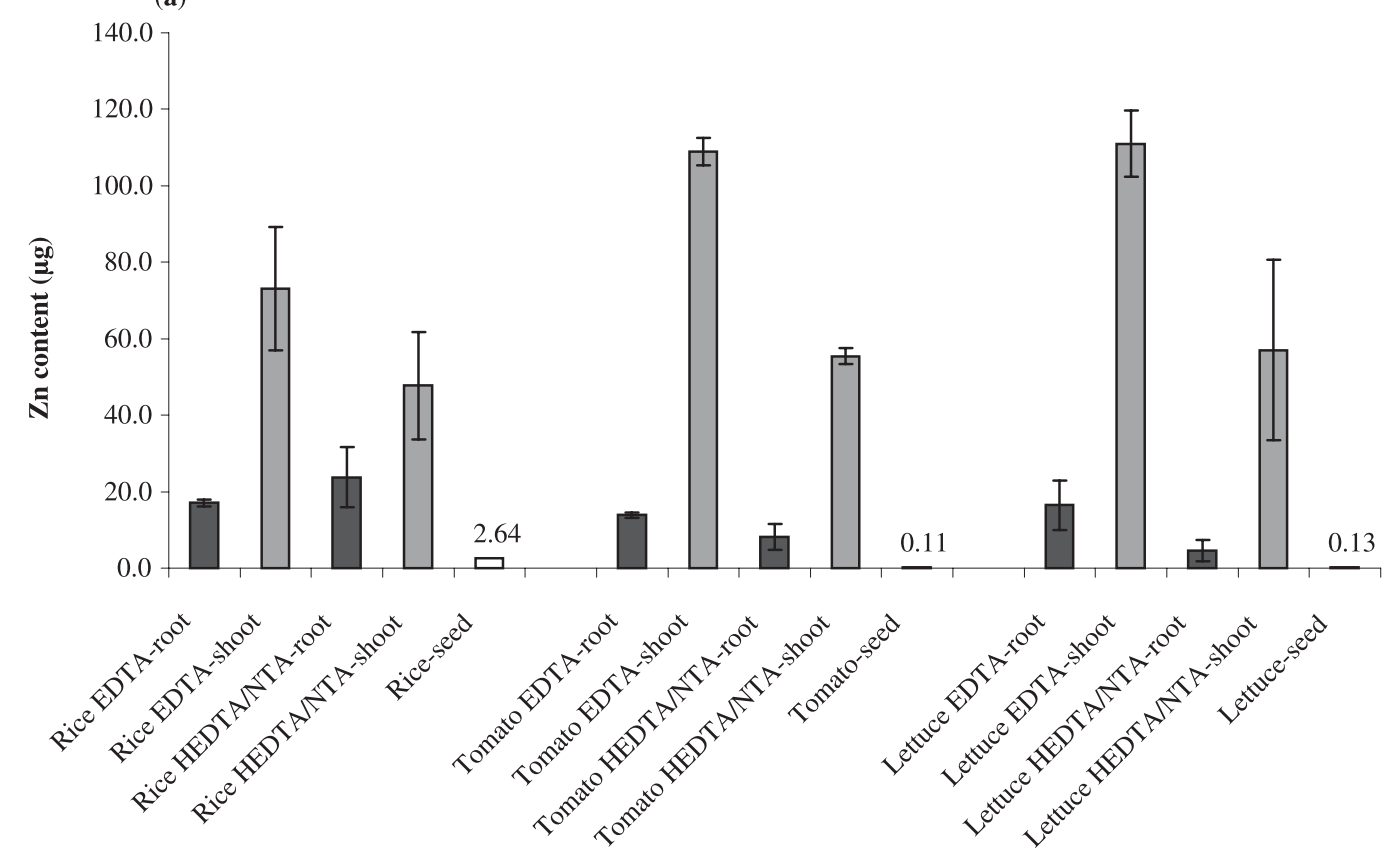

(b)

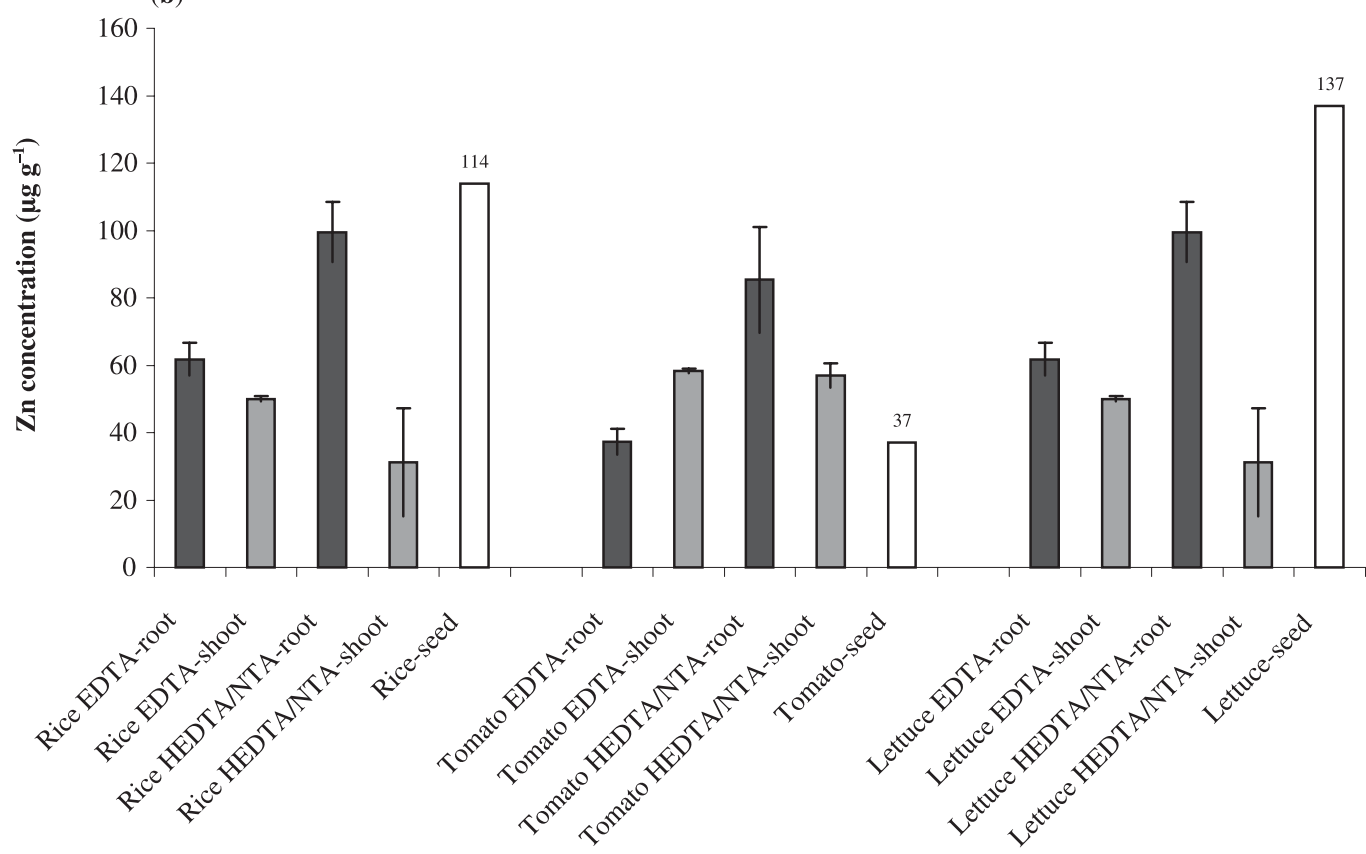

Fig. 2 Average root, shoot and seed zinc ( $\mathrm{Zn}$ ) contents (a) and concentration (b) of rice (Oryza sativa), lettuce (Lactuca sativa) and tomato (Lycopersicon esculentum) per experimental pot containing five plants after $42 \mathrm{~d}$ of growth. The error bars indicate $\pm 1 \mathrm{SD}, n=4$ (unless for seeds, with $n=1$ ).

$\mathrm{Zn}$ in the solution than in the roots, this effect will only be minor.

The enrichment of light $\mathrm{Zn}$ in the free $\mathrm{Zn}^{2+}$ pool will be greater in the HEDTA + NTA solution than in the EDTA solution. Consistent with this and preferential absorption of free $\mathrm{Zn}^{2+}$ by the roots, the plants in HEDTA + NTA solution show a larger negative isotopic shift than the plants in EDTA. Because in general much of the $\mathrm{Zn}$ in soil solutions is complexed with humic substances and other organic ligands, at least in uncontaminated soils (Tipping, 2002; Kirk, 2004), this result will apply in natural systems in general, though the degree of binding by the various naturally occurring ligands will be different. 


\section{Uptake by roots}

The fact that the isotopic composition of the shoots varies between the plant species (Fig. 1) strongly suggests that biologically mediated isotopic discrimination occurs during uptake or translocation or both. The mechanisms controlling $\mathrm{Zn}$ transport across the root and other cell membranes are not well understood (Hacisalihoglu et al., 2001; Hacisalihoglu \& Kochian, 2003), but they are thought to be metabolically controlled and involve some combination of transfer along the electrochemical gradient via ion channels, carrier proteins or against the electrochemical gradient via electrogenic pumps. Carrier-mediated transport should favour the heavy isotope because it involves covalent binding to a carrier protein on the outer side of the membrane, with subsequent release on the inner side as a result of conformational changes in the carrier. However, transport through ion channels or via electrogenic pumps will favour the light isotope because of its greater diffusion coefficient. The observed net enrichment of the shoots and of the plants as a whole with the light isotope, and the differences between the plant species, therefore suggests that membrane transport is dominated by ion channels and electrogenic pumps rather than by carrier-mediated transport. However, it is not possible with the current data to separate these effects from the bias in favour of the light isotope caused by speciation in the external solution.

A further factor is that the preferential removal of heavy $\mathrm{Zn}$ during binding to root cell walls (next section) will tend to bias the labile $\mathrm{Zn}$ pool in the root apoplast in favour of light $\mathrm{Zn}$, and hence will bias uptake into root cells and translocation to the shoots in favour of light $\mathrm{Zn}$. However, this would neither explain the absence of differences in fractionation in the roots between the different nutrient solutions nor the differences between plant species. Also, from the root : shoot partitioning of $\mathrm{Zn}$ (Fig. 2), the flux to the shoots is far greater than that to compartments in the roots, and so the isotopic composition of the apoplast will be dominated by fractionation occurring in uptake into the plant rather than in retention on root cell walls.

\section{Binding to root cell walls}

Some proportion of the $\mathrm{Zn}$ in the root apoplast will become bound to the external surfaces of root cell walls in nonexchangeable forms due to covalent bonding to carbonyl and hydroxyl groups in the cell walls (Santa Maria \& Cogliatti, 1988; Lasat et al., 1996; Hart et al., 1998). Reid et al. (1996) showed that more than $90 \%$ of cell-associated $\mathrm{Zn}$ is retained in cell walls and several per cent of this is in nonexchangeable forms. Because heavy $\mathrm{Zn}$ will be preferentially bound, this would explain the positive shift of the isotope ratio to heavier $\mathrm{Zn}$ in the total root digests. We found no change in isotopic composition of rice roots leached with $\mathrm{LaCl}_{3}$ solution for $10 \mathrm{~min}$; however, this regime would not have removed all the nonexchangeable Zn (Reid et al., 1996).
The positive shift in the roots is similar in all three plant species regardless of solution composition and the different isotope distribution in the solutions. A possible explanation is that free and complexed $\mathrm{Zn}$ are adsorbed on the root walls in the proportions in which they occur in the solutions, so that any isotopic discrimination resulting from speciation in the solution is not apparent in the root digests. However, it is unlikely that complexed $\mathrm{Zn}$ is adsorbed to anything like the extent of $\mathrm{Zn}^{2+}$, so we reject this explanation. An alternative explanation is that the isotopic composition of $\mathrm{Zn}$ in the root apoplast is enriched in the heavier isotope compared with the bulk solution as a result of preferential uptake of light $\mathrm{Zn}^{2+}$ into root cells and diffusion limitations in transfer of $\mathrm{Zn}^{2+}$ to the root surface. An unstirred layer of $c .10-100 \mu \mathrm{m}$ thickness surrounds individual roots even in stirred solutions (Grignon \& Sentenac, 1991). This is thin enough for the root surface to be regarded as a plane without serious error, hence the flux, $F$, of $\mathrm{Zn}$ across the unstirred layer is given by $F=D\left(C_{\infty}-C_{0}\right) /$ $\delta x$, where $D$ is the diffusion coefficient, $\delta x$ is the layer thickness and $C_{\infty}-C_{0}$ is the concentration difference across the layer. A typical flux of $\mathrm{Zn}$ into plant roots is $10^{-14} \mathrm{~mol} \mathrm{~cm}^{-2}$ $\mathrm{s}^{-1}$ (Tinker $\&$ Nye, 2000, chapter 5), so if $\delta x=100 \mu \mathrm{m}$ and $D=10^{-5} \mathrm{~cm}^{2} \mathrm{~s}^{-1}$, then $C_{\infty}-C_{0}=10^{-8} \mathrm{M}$. This is small compared with the free $\mathrm{Zn}^{2+}$ concentration in the EDTA solution $\left(10^{-7} \mathrm{M}\right)$, but two orders of magnitude greater than that in the HEDTA + NTA solution $\left(10^{-10} \mathrm{M}\right)$. Buffering of free $\mathrm{Zn}^{2+}$ by dissociation of complexed $\mathrm{Zn}$ is slow compared with diffusion of $\mathrm{Zn}^{2+}$ across the unstirred layer (Stumm \& Morgan, 1996, pp. 318-319), so would not greatly alter the above calculations. Hence the calculations indicate that the free $\mathrm{Zn}^{2+}$ concentration at the root surfaces in the HEDTA + NTA solution will be extremely small and that its isotopic composition will be highly sensitive to discriminatory processes. The greater the flux of light $\mathrm{Zn}^{2+}$ into the roots, the greater will be its depletion at the root surface, so the differences in isotopic discrimination between the different nutrient solutions will be offset, explaining the lack of differences in binding to roots. A test of this explanation would be the extent to which the isotopic discrimination depended on stirring of the solution and consequent changes in thickness of the unstirred layer.

\section{Translocation from roots to shoots}

The root : shoot partitioning of $\mathrm{Zn}$ in the three plant species indicates an efficient $\mathrm{Zn}$ transfer from root to shoot, with typically over $75 \%$ of the $\mathrm{Zn}$ being transferred to the shoot (Fig. 2). The shoots will therefore tend to inherit an isotopic composition similar to the average composition of $\mathrm{Zn}$ taken across the root cell membranes. There may be further discrimination where the $\mathrm{Zn}$ crosses cell membranes between the roots and shoots. Presumably this discrimination would be similar to that occurring in transfer across the root cell membranes.

The fact that isotopic fractionation in the shoots differs between the nutrient solutions, whereas that in the roots does 
not, is evidence that at least two discriminatory processes are operating and that they affect the roots and shoots differently. The fractionation in the shoots and its dependence on the nutrient solution composition are consistent with the effects of solution speciation discussed earlier, possibly but not necessarily compounded by discrimination during membrane transport into and within the plants. The fractionation in the roots requires some process that is independent of the composition of the nutrient solution, such as binding to root cell walls coupled to diffusion limitations in light $\mathrm{Zn}$ uptake as discussed earlier.

\section{Concluding remarks}

The observed isotopic depletion in heavy $\mathrm{Zn}$ from root to shoot $(-0.13$ to $-0.26 \%$ pamu) accounts for roughly a quarter of the total reported terrestrial variability of $\mathrm{Zn}$ isotopic compositions ( $0.84 \%$ o pamu). This suggests that plant uptake is an important source of isotopic variation in biogeochemical cycling of $\mathrm{Zn}$. However, the shift during plant $\mathrm{Zn}$ uptake is small compared with that produced in industrial processes (up to 5\%o pamu, Marcus \& Zevenbergen, 1999; Mason et al., 2004b), so the industrial isotopic discrimination is not likely to be overprinted during plant uptake. Hence discrimination in plant uptake will probably not compromise $\mathrm{Zn}$ stable isotopes as a tool for tracing environmental pollution, although it is possible that plant-induced fractionation is cumulative depending on mass balances and recycling of biologically incorporated $\mathrm{Zn}$ in soils. Our explanations for the observed fractionations are somewhat speculative and clearly need further investigation. Nonetheless, the effects shown indicate that isotopic fractionation could be a useful tool for studying $\mathrm{Zn}$ uptake and translocation in plants, without the need for excessively large and physiologically unrealistic $\mathrm{Zn}$ concentrations or artificially enriched isotopes.

\section{Acknowledgements}

We thank Imperial College London (Mike Warner), the Natural History Museum (Andy Fleet) and Rothamsted Research (Steve McGrath) for access to facilities; NERC and the Leverhulme Trust for financial support to run the laboratories; Terry Williams, Eta Mullane, Malin Kylander, Helen Crowther, Jamie Wilkinson and Laura Sigg for practical help in the laboratory and fruitful discussions; and Francis Albarède and three anonymous reviewers for very helpful comments. Rothamsted Research receives grant aided support from the Biotechnology and Biological Sciences Research Council of the United Kingdom. DJW dedicates this paper to Eralys, Gustavo and El Camino.

\section{References}

Anbar AD, Roe JE, Barling J, Nealson KH. 2000. Non-biological fractionation of iron isotopes. Science 288: 126-128.
Beard BL, Johnson CM, Skulan JL, Nealson KH, Cox L, Sun H. 2003. Application of $\mathrm{Fe}$ isotopes to tracing the geochemical and biological cycling of Fe. Chemical Geology 195: 87-117.

Bigeleisen J, Mayer MG. 1947. Calculation of equilibrium constants for isotopic exchange reactions. Journal of Chemical Physics 15: 261-267.

Dolgopolova A, Weiss D, Seltmann R, Coles B. 2004. Improved closed vessel microwave digestion method for lichens. International Journal of Environmental Analytical Chemistry 84: 889-899.

Grignon C, Sentenac H. 1991. $\mathrm{pH}$ and ionic conditions in the apoplast. Annual Review of Plant Physiology and Plant Molecular Biology 402: 103-128.

Hacisalihoglu G, Hart JJ, Kochian LV. 2001. High- and low-affinity zinc transport systems and their possible role in zinc efficiency in bread wheat. Plant Physiology 125: 456-463.

Hacisalihoglu G, Kochian LV. 2003. How do some plants tolerate low levels of soil zinc? Mechanisms of zinc efficiency in crop plants. New Phytologist 159: 341-350.

Halliday AN, Lee DC, Christensen JN, Rehkaemper M, Yi W, Luo X, Hall CM, Ballentine CJ, Pettke T, Stirling C. 1998. Applications of multiple collector-ICPMS to cosmochemistry, geochemistry, and paleoceanography. Geochimica et Cosmochimica Acta 62: 919-940.

Hart JJ, Wendell AN, Welch RM, Sullivan A, Kochian LV. 1998. Characterisation of zinc uptake, binding, and translocation in intact seedlings of bread and durum wheat cultivars. Plant Physiology 118: 219-226.

Hoefs J. 1987. Stable Isotope Geochemistry. New York, USA: Springer Verlag. Kirk GJD. 2004. The Biogeochemistry of Submerged Soils. Chichester, UK: John Wiley and Sons.

Lasat MM, Baker AJM, Kochian LV. 1996. Physiological characterisation of root $\mathrm{Zn}^{2+}$ absorption to shoots in $\mathrm{Zn}$ hyperaccumulator and nonaccumulator species of Thlaspi. Plant Physiology 112: 1715-1722.

Marcus C, Zevenbergen LA. 1999. The reduction and distillation of isotopically enriched zinc oxides under high vacuum conditions. Nuclear Instruments and Methods in Physics Research, A 438: $30-35$.

Maréchal CN, Albarède F. 2002. Ion-exchange fractionation of copper and zinc isotopes. Geochimica et Cosmochimica Acta 66: 1499-1509.

Maréchal CN, Nicolas E, Douchet C, Albarède F. 2000. Abundance of zinc isotopes as a marine biogeochemical tracer. Geochemistry Geophysics Geosystems 1: 1999GC000029.

Maréchal CN, Télouk P, Albarède F. 1999. Precise analysis of copper and zinc isotopic compositions by plasma-source mass spectrometry. Chemical Geology 156: 251-273

Mason TFD. 2003. High precision transition metal isotope analysis by plasma-source mass spectrometry and implications for low temperature geochemistry. PhD thesis, Imperial College, London.

Mason TFD, Weiss DJ, Horstwood M, Parrish RR, Russell SS, Mullane E, Coles BJ. 2004a. High precision $\mathrm{Cu}$ and $\mathrm{Zn}$ isotope analysis by plasma source mass spectrometry: Part 1: Spectral interferences and their correction. Journal of Analytical Atomic Spectrometry 19: 209-217.

Mason TFD, Weiss DJ, Horstwood M, Parrish RR, Russell SS, Mullane E, Coles BJ. 2004b. High precision $\mathrm{Cu}$ and $\mathrm{Zn}$ isotope analysis by plasma source mass spectrometry: Part 2: Correcting for mass bias discrimination effects. Journal of Analytical Atomic Spectrometry 19: 218-226.

Parker DR, Norvell WA, Chaney RL. 1995. GEOCHEM-PC: A chemical speciation program for IBM and compatible personal computers. In: Loeppert H, ed. Soil chemical equilibrium and reaction models, Vol. 42. SSSA Special Publication. Madison, WI, USA: Soil Science Society of America, 253-269.

Price NM, Harrison GI, Hering JG, Nirel P, Palenik B, Morel FMM. 1998. Preparation and chemistry of the artificial culture medium aquil. Biological Oceanography 6: 443-461. 
Reid RJ, Brookes JD, Tester MA, Smith FA. 1996. The mechanism of zinc uptake in plants - Characterisation of the low-affinity system. Planta 198: 39-45.

Rengel Z. 1999. Physiological responses of wheat genotypes grown in chelator- buffered nutrient solutions with increasing concentrations of excess HEDTA. Plant and Soil 215: 193-202.

Santa Maria GE, Cogliatti DH. 1988. Bidirectional Zn-fluxes and compartimentation in wheat seedling roots. Journal of Plant Physiology 132: 312-315.

Stumm W, Morgan JJ, eds. 1996. Aquatic Chemistry, 3rd edn. New York, USA: John Wiley and Sons.
Taiz L, Zeiger E, eds. 2002. Plant Physiology, 3rd edn. Sunderland, MA, USA: Sinauer Associates, Inc. Publishers.

Tinker PB, Nye PH. 2000. Solute Movement in the Rhizosphere. New York, USA: Oxford University Press.

Tipping F. 2002. Cation Binding by Humic Substances. Cambridge, UK: Cambridge University Press.

Zhu XK, Guo Y, Williams RJP, O’Nions RK, Matthews A, Belshaw NS, Canters GW, de Wall EC, Weser U, Burgess BK, Salvato B. 2002. Mass fractionation processes of transition metal isotopes. Earth and Planetary Science Letters 200: $47-62$.

\section{About New Phytologist}

- New Phytologist is owned by a non-profit-making charitable trust dedicated to the promotion of plant science, facilitating projects from symposia to open access for our Tansley reviews. Complete information is available at www.newphytologist.org.

- Regular papers, Letters, Research reviews, Rapid reports and Methods papers are encouraged. We are committed to rapid processing, from online submission through to publication 'as-ready' via OnlineEarly - the 2003 average submission to decision time was just 35 days. Online-only colour is free, and essential print colour costs will be met if necessary. We also provide 25 offprints as well as a PDF for each article.

- For online summaries and ToC alerts, go to the website and click on 'Journal online'. You can take out a personal subscription to the journal for a fraction of the institutional price. Rates start at $£ 109$ in Europe/\$202 in the USA \& Canada for the online edition (click on 'Subscribe' at the website).

- If you have any questions, do get in touch with Central Office (newphytol@lancaster.ac.uk; tel +44 1524 592918) or, for a local contact in North America, the USA Office (newphytol@ornl.gov; tel 865576 5261). 